\begin{tabular}{|l|l|l}
\hline & $\begin{array}{l}\text { Proceedings of the } \\
\text { Informing Science }+\end{array}$ & $\begin{array}{l}\text { An Official Publication } \\
\text { of the Informing Science Institute } \\
\text { InformingScience.org }\end{array}$ \\
\hline
\end{tabular}

Online July 6-7, 2021

\title{
Developing a Big DATA Success MOdEL IN Organizations: A GROUNDED THEORY METHOD [ABSTRACT]
}

\begin{tabular}{|c|c|c|}
\hline Tao "Eric" Hu* & $\begin{array}{l}\text { California State University at } \\
\text { Northridge, Northridge, California, } \\
\text { USA }\end{array}$ & eric.hu@,csun.edu \\
\hline Hua Dai & $\begin{array}{l}\text { California State University at Chan- } \\
\text { nel Islands, Camarillo, California, } \\
\text { USA }\end{array}$ & hua.dai@,csuci.edu \\
\hline Ping Zhang & $\begin{array}{l}\text { Middle Tennessee State University, } \\
\text { Murfreesboro, Tennessee, USA }\end{array}$ & pzhang@mtsu.edu \\
\hline
\end{tabular}

\section{ABSTRACT}

Aim/Purpose

In spite of the insights in paving solid grounds and avenues for meaningful studies, the predicament of the literature in lacking fruitful understanding of the critical success factors and models of Big Data remain elusive and unexplored. A systematic literature review of research topics, perspectives, and substantial findings of Big Data is needed, so an overarching framework of Big Data success can be developed to integrate findings and systematically guide future research for advancing IS theoretical and practical progressing.

Background

$$
\begin{aligned}
& \text { This study (1) uses the grounded theory as a literature review method to } \\
& \text { search and collect Big Data studies in the AIS "Senior Scholars' Basket of } \\
& \text { Journals" over the period of twenty years from } 2000 \text { to 2020, (2) employs } \\
& \text { data coding and content analysis of the grounded theory to conduct a sys- } \\
& \text { tematic literature review of research concepts, categories, topics, methodolo- } \\
& \text { gies, and models and paradigms of Big Data in IS discipline, and (3) upon } \\
& \text { synthesis of theoretical perspectives and empirical findings, develops a Big } \\
& \text { Data success theory with a research agenda to enrich the cumulative } \\
& \text { knowledge of critical success factors and interrelationships of Big Data in } \\
& \text { the organizational contexts. }
\end{aligned}
$$

Accepted by Editor Michael Jones | Received: February 7, 2021 | Revised: April 28, 2021 | Accepted: May 2, 2021.

Cite as: Hu, T. E., Dai, H., \& Zhang, P. (2021). Developing a big data success model in organizations: A grounded theory method [Abstract]. In M. Jones (Ed.), Proceedings of InSITE 2021: Informing Science and Information Technology Education Conference, Article 9. Informing Science Institute. https://doi.org/10.28945/4772

(CC BY-NC 4.0) This article is licensed to you under a Creative Commons Attribution-NonCommercial 4.0 International License. When you copy and redistribute this paper in full or in part, you need to provide proper attribution to it to ensure that others can later locate this work (and to ensure that others do not accuse you of plagiarism). You may (and we encourage you to) adapt, remix, transform, and build upon the material for any non-commercial purposes. This license does not permit you to use this material for commercial purposes. 
Big Data Success Theory

Methodology A grounded theory-based review of Big Data literature helps investigate the emerging and evolving theoretical foundations of the subject, and create a roadmap for advancing IS theory and business relevance.

Contribution The research in critical success factors and models of Big Data presents a novel opportunity for advancing IS theory across different IS traditions and paradigms.

Findings While this study is still in progress, currently we report preliminary findings in research methodologies, topics, and abstractions of open coding. Research of next steps toward a Big Data success theory is also reported in the submitted abstract. As the study proceeds, we expect more in-depth findings to be reported in the conference presentation in July, 2021.

Recommendations The findings of this study shall enrich our understanding of how organizafor Practitioners tions transform Big Data potentials into organizational performance and economic value.

Recommendations for Researchers

The research in critical success factors and models of Big Data presents a novel opportunity for advancing IS theory across different IS traditions and paradigms.

Impact on Society The findings of this study shall enrich the cumulative knowledge of critical success factors and interrelationships of Big Data in the organizational contexts.

Future Research Future research may consider collecting the literature data from a wider variety of journal outlets and capture more relevant critical success factors and interrelationships of Big Data for the theory development.

Keywords grounded theory, Big Data, IS research, literature review, success theory 


\section{AUTHORS}

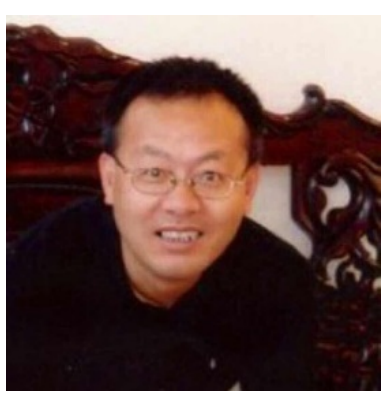

Research, and others.

Dr. Tao "Eric" Hu is an Assistant Professor at the Department of Accounting \& Information Systems (IS) of David Nazarian College of Business \& Economics of California State University - Northridge. He teaches courses in IS and data analytics. His research focuses on areas such as service innovation, business analytics, and IS cross-cultures. He has published studies in leading IS journals such as Information \& Management, European Journal of Information Systems, Communications of the Association for Information Systems, ACM Transactions on Software Engineering and Methodology, Journal of Computer Information Systems, Journal of Electronic Commerce

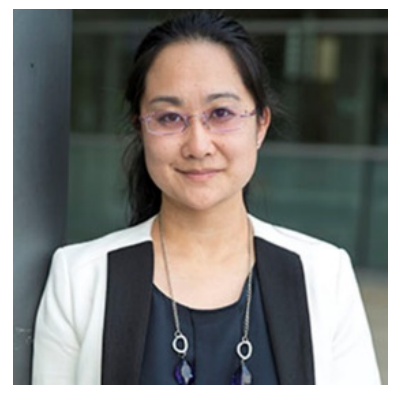

Dr. Hua Dai is a Professor of Management Information Systems of Martin V. Smith School of Business \& Economics of California State University - Channel Islands. She teaches courses in IS and data analytics. Her research interests include service in electronic mediated environment, social media, electronic/social commerce, data analytics, telecommunication policies and standards, privacy and security, and cross-cultural research. Her research has been published in Information \& Management, Decision Support Systems, The Data Base for Advances in Information Systems, Electronic Markets, ACM Transactions on Software Engineering and Methodology, Journal of Computer Information Systems, Journal of Electronic Commerce Research, and others.

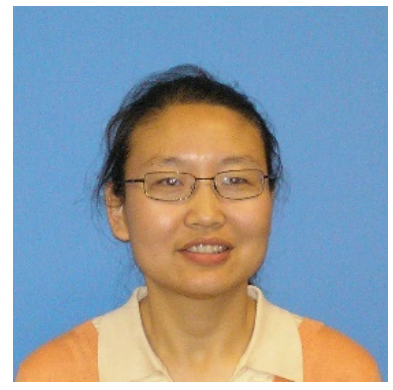

Dr. Ping Zhang is an Associate Professor at the Department of Mathematical Sciences of Middle Tennessee State University. She teaches courses in statistics and applied mathematics. Her research focuses on areas such as data analytics and biostatistics in AIDS and cancer. 